Jurnal Riset Sistem Informasi Dan Teknik Informatika (JURASIK)

Volume 5 Nomor 1 Februari, pp 127-137

ISSN: 2527-5771/EISSN: 2549-7839

http://tunasbangsa.ac.id/ejurnal/index.php/jurasik

\title{
Pengukuran Kinerja Pondok Pesantren Menggunakan Analitycal Hierarchy Process
}

\author{
Nur Kartika Oktafiani, Arini Rifqiya Wahdati, Faldadinda Farin Maharani, M. Ainul Yaqin \\ Jurusan Teknik Informatika, Fakultas Sains dan Teknologi \\ Universitas Islam Negeri Maulana Malik Ibrahim Malang \\ Jl. Gajayana no 50 Lowokwaru , Malang \\ nurkartikaok@gmail.com,diajengarinirifqiya@gmail.com, faldadinda@gmail.com,yaqinov@ti.uin- \\ malang.ac.id
}

\begin{abstract}
Performance is a measure of the success of an organization. The success of an organization is illustrated by the achievements produced with the standard objectives of the organization. to find out the success of an organization it is necessary to measure systematically and rationally so that the goals to be achieved are implemented well. Islamic Boarding School with Analitycal Hierarchy Process (AHP) method. The Analytical Hierarchy Process (AHP) can be used to formulate the priorities of various choices by using several criteria (multi criteria). Recommended criteria are obtained from 52 standard Islamic boarding school data. It is expected to be known: 1) daily performance, 2) weekly performance, 3) monthly performance, 4) annual performance. The results of this study can be seen how great the performance of Islamic Boarding School is.
\end{abstract}

Keywords: Performance, Islamic Boarding School, Analytical Hierarchy Process

\begin{abstract}
Abstrak
Kinerja menjadi sebuah tolak ukur bagi keberhasilan suatu organisasi. Keberhasilan tersebut dapat digambarkan melalui capaian yang dihasilkan yang sesuai dengan standar tujuan dari organisasi tersebut. Untuk mengetahui keberhasilan suatu organisasi maka dibutuhkan cara mengukur yang sistematis dan rasional agar tujuan akhir pencapaian dapat didapatkan dengan baik. Penelitian ini bertujuan mengukur kinerja Pondok Pesantren dengan metode Analitycal Hierarchy Process (AHP). Analitycal Hierarchy Process (AHP) dapat digunakan untuk menyusuun prioritas dari berbagai pilihan dengan menggunakan beberapa kriteria (multi criteria). Kriteria yang dimaksud didapat dari data 52 standar Pondok Pesantren. Sehingga akan diketahui: 1) kinerja harian, 2) kinerja mingguan, 3)kinerja bulanan, 4) kinerja tahunan. Hasil dari penelitian ini yaitu dapat diketahui besar pencapaian kinerja Pondok Pesantren.
\end{abstract}

Kaca Kunci: Kinerja, Pondok Pesantren, Analytical Hierarchy Process

\section{PENDAHULUAN}

Pondok pesantren merupakan lembaga pendidikan islam sebagai sebuah produk budaya yang telah lama dikembangkan oleh masyarakat Indonesia. Berawal dari sebuah kesadaran terhadap pentingnya pendidikan bagi orang-orang pribumi maka lahirlah sebuah lembaga pendidikan, khususnya pendidikan islam, yang disebut pesantren. Sebagai sebuah produk budaya, pondok pesantren mempunyai sebuah ciri khas yang unik dan telah menjadi pola yang mengakar dan berkembang dalam masyarakat. Pondok pesantren menciptakan sebuah bentuk lingkungan mereka 
Jurnal Riset Sistem Informasi Dan Teknik Informatika (JURASIK)

Volume 5 Nomor 1 Februari, pp 127-137

ISSN: 2527-5771/EISSN: 2549-7839

http://tunasbangsa.ac.id/ejurnal/index.php/jurasik

sendiri dengan tata nilai kehidupan positif sebagai kultur dan unsur utama di dalamnya.

Secara historis, pondok pesantren memang dilahirkan sebagai sebuah kelompok yang menjalankan sebuah dakwah islam. Pada mulanya dibentuk secara tradisional sebagai sebuah perkumpulan pengajian yang akhirnya kemudian berkembang dengan segala sarana dan prasarananya. Melewati semua itu, dengan segala keunikan dan kekhasnya, pondok pesntren juga diharapkan menjadi kontributor terhadap berkembangnya pendidikan secara umum di Indonesia. Pondok pesantren diharapkan menjadi sebuah lembaga pendidikan yang professional dalam memenuhi tantangan arus globalisasi saat ini dengan tidak menghilangkan ciri khas yang mereka punya. Melihat kenyataan tersebut, maka pondok pesantren diarahkan untuk mengelola lembaganya dengan standar profesionalisme yang signifikan dan terstruktur di tengah riuhnya industrialisasi dan perkembangan teknologi modern.

Pada tahun 2003, Welsh Assembly Government mengeluarkan sebuah standart untuk sebuah boarding school yang berjumlah 52 standart. Menurut pernyataan mereka, minimum standart tersebut berlaku atau dapat diaplikasikan terhadap setidaknya 3 lembaga yang mereka sebutkan, antara lain: sekolah residential khusus; sekolah asrama khusus; dan perguruan tinggi atau pendidikan lanjut yang mengakomodasi siswa di bawah usia 18 tahun. Secara umum, standart ini dapat dijadikan sebagai sebuah acuan untuk memulai memberikan pengukuran terhadap pondok pesantren di Indonesia.

\section{METODOLOGI PENELITIAN}

\subsection{Pengukuran Kinerja}

Sistem pengukuran kinerja digambarkan sebagai bagian integral dari sistem akuntansi manajemen yang memberikan informasi untuk mendorong manajer berpikir strategis tentang bagaimana kegiatan mereka cocok dengan yang lain bagian dari perusahaan, dan dapat membantu mereka dalam mengelola operasi perusahaan. Proses pengukuran kinerja saat ini difokuskan pada pengelolaan aset yang bersifat non-finansial, daripada mengelola bersifat finansial. tekanan dari pesaing dan pelanggan domestik dan global, tuntutan untuk kualitas dan dapat menfandalkan produk, harapan yang tinggi dari para stakeholder dan penggunaan teknologi manufaktur yang baru dan canggih. Semua yang berkontribusi sebagai dorongan utama untuk merancang dan merancang sistem pengukuran kinerja yang baik untuk suatu perusahaan yang dapat menyediakan apa yang dibutuhkan untuk memenuhi tujuannya.

\subsection{Pondok Pesantren}

Pesantren merupakan tempat di mana santri, guru / kyai atau perwakilannya belajar secara formal, non-formal, dan informal waktu di pagi hari, di siang hari, atau di malam hari. Pesantren telah terbukti berhasil dalam mendidik santrinya dan 
Jurnal Riset Sistem Informasi Dan Teknik Informatika (JURASIK)

Volume 5 Nomor 1 Februari, pp 127-137

ISSN: 2527-5771/EISSN: 2549-7839

http://tunasbangsa.ac.id/ejurnal/index.php/jurasik

menciptakan pendidikan karakter yang baik dan pemimpin agama berkualitas tinggi. Hal itu terjadi karena metode pengajaran yang dikembangkan sangat efektif di mana fokus pada bimbingan pribadi oleh kyai (guru) dan pemahaman kualitatif siswa bukan hanya aspek kognitif melalui perkuliahan. Ini juga memprioritaskan moral siswa dan aspek spiritual. Selain itu, juga melatih dan meningkatkan sikap siswa tentang menghargai nilai-nilai spiritual dan kemanusiaan, menanamkan perilaku baik seperti kejujuran, moralitas serta mempersiapkan mereka untuk mengakui etika agama islam yang baik dan benar [1].

Kelembagaan pondok pesantren tidak dapat dilepaskan dari kehidupan muslim di wilayah Indonesia. Pondok pesantren telah dikenal sejak saat pertama Islam diperkenalkan di Indonesia yaitu pada abad ketujuh, tetapi keberadaan dan pembangunan menjadi populer di abad keenam puluh. Sejak itu, banyak yang pondok pesantren pesantren telah mengajarkan berbagai buku Islam klasik dalam fiqh, aqidah, tasawuf, dan menjadi pusat penyiaran Islam [2].

\subsection{Analytic Hierarchy Process (AHP)}

Analytical Hierarchy Process (AHP) adalah alat yang biasa digunakan pada pengambilan keputusan dengan kriteria majemuk. AHP merupakan sebuah hirarki fungsional dengan input utamanya persepsi manusia, dengan AHPsuatu masalah yang kompleks dan tidak terstruktur dikelompokkan dan diatur menjadi suatu bentuk hirarki, karena semua bagian dari hirarki saling berhubungan, maka akan sangat mudah melihat bagaimana suatu perubahan dalam satu pespektif akan memberikan pengaruh bagi perspektif yang lainnya [4]. Setiap elemen yang ada dpada hirarki harus diketahui terlebih dahulu bobot relatifnya. Tujuannya adalah untuk mengetahui tingkat kepentingan/prefernsi pihak-pihak yang berkepentingan dalam permasalahan terhadap kriteria/elemen dan struktur hirarki sistem secara keseluruhan. Langkah awal yang harus dilakukkan dalam menentukan susunan prioritas elemen adalah menyusun perbandingan berpasangan (pairwise comparison), yaitu membandingakan dalam bentuk berpasangan semua elemen untuk setiap hirarki.

\subsection{Metode Penelitian}

a) Identifikasi Masalah

Identifikasi masalah merupakan tahap pertama dimana penulis merumuskan masalah-masalah apa saja yang nantinya akan diangkat dalam jurnal pengukuran kinerja pondok pesantren.

b) Studi Literatur

Referensi yang dikaji dipenelitian ini dalam menyelesaikan penelitian ini diantaranya dokumen

c) Pengumpulan Data

Metode pengumpulan data yang dilakukan ialah dengan melakukan observasi yakni mengadakan pengamatan langsung pada kegiatan yang dilakukan oleh pondok 
Jurnal Riset Sistem Informasi Dan Teknik Informatika (JURASIK)

Volume 5 Nomor 1 Februari, pp 127-137

ISSN: 2527-5771/EISSN: 2549-7839

http://tunasbangsa.ac.id/ejurnal/index.php/jurasik

pesantren. Selain observasi penulis juga melakukan wawancara kepada pihak pondok pesantren guna mendapatkan info valid.

d) Penerapan Metode AHP

Menurut [5], Tahapan-tahapan dalam menerapkan metode AHP dapat dilakukan sebagaimana berikut:

1. Definisi awal terhadap masalah dan solusi yang dipilih.

2. Menggambarkan setiap elemen menggunakan hierarki dan tujuan utama sebagai elemen awal.

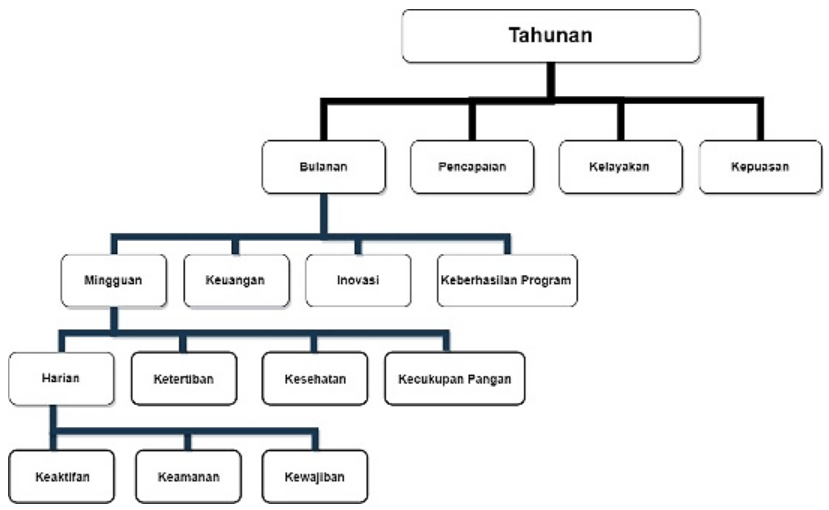

Gambar 1. hirarki kinerja pondok pesantren

3. Membuat pairwise comparison matrix (matrik perbandingan berpasangan) guna memberikan gambaran kontribusi atau pengaruh untuk setiap elemen yang terlibat terhadap kriteria yang setingkat di atasnya.

Tabel 1. Matriks perbandingan berpasangan

\begin{tabular}{|c|c|c|c|c|}
\hline & Kriteria-1 & Kriteria-2 & Kriteria-3 & Kriteria-n \\
\hline Kriteria-1 & K11 & K12 & K13 & K1n \\
\hline Kriteria-2 & K21 & K22 & K23 & K2n \\
\hline Kriteria-3 & K31 & K32 & K33 & K3n \\
\hline Kriteria-m & Kn1 & Kn2 & Kn3 & Kmn \\
\hline
\end{tabular}

4. Memberikan nilai pada matrik perbandingan berpasangan sehingga diperoleh nilai total yaitu $\mathrm{n} \times[(\mathrm{n}-1) / 2]$ buah, dengan $\mathrm{n}$ adalah jumlah elemen seluruhnya yang dibandingkan.

Tabel 2. Skala penilaian perbandingan berpasangan.

\begin{tabular}{|c|l|}
\hline Intensitas Kepentingan & \multicolumn{1}{c|}{ Keterangan } \\
\hline 1 & Equal Importance \\
\hline 3 & Slightly more Importance \\
\hline
\end{tabular}


Jurnal Riset Sistem Informasi Dan Teknik Informatika (JURASIK)

Volume 5 Nomor 1 Februari, pp 127-137

ISSN: 2527-5771/EISSN: 2549-7839

http://tunasbangsa.ac.id/ejurnal/index.php/jurasik

\begin{tabular}{|c|l|}
\hline Intensitas Kepentingan & \multicolumn{1}{c|}{ Keterangan } \\
\hline 5 & Materially more Importance \\
\hline 7 & Significantly more Importance \\
\hline 9 & Compromise values \\
\hline $2,4,6,8$ & Compromise values \\
\hline
\end{tabular}

5 Melakukan perhitungan nilai eigen dan pengujan konsistensi. Jika nilai konsisten tidak ditemukan maka harus dilakukan pengambilan data ulang.

6 Melakukan perulangan pada langkah 3, 4,dan 5 untuk seluruh tingkat hierarki.

7 Melakukan perhitungan untuk mencari vektor eigen untuk setiap matriks perbandingan berpasangan untuk mendapatkan bobot setiap elemen yang digunakan sebagai penentu prioritas elemen bersangkutan pada hierarki.

\section{HASIL DAN PEMBAHASAN}

\subsection{Pengukuran terhadap masing- masing rasio pada tiap-tiap bagian waktu menggunakan rumus sebagai berikut:}

a. Mengukur kinerja harian

Rasio-rasio yang dipilih melalui 52 standar minimum pondok pesantren yang diacu untuk mewakili kinerja harian:
1) Keaktifan santri (H1) $=\frac{\text { Jumlah kehadiran santri pada kegiatan }}{\text { Total jumlah seluruh santri }} \times 100 \%$
2) Keamanan $(\mathrm{H} 2)=\frac{\text { Jumlah kasus kejahatan terhadap santri }}{\text { Total jumlah seluruh santri }} \times 100 \%$
3) Kebersihan (H3) $=\frac{\text { Jumlah tempat/lokal yang bersih }}{\text { Total jumlah seluruh tempat } / \text { lokal }} \times 100 \%$

b. Mengukur kinerja mingguan

Rasio-rasio yang dipilih melalui 52 standar minimum pondok pesantren yang diacu untuk mewakili kinerja mingguan:
1) Ketertiban (M1) $=\frac{\text { Jumlah pelanggaran berat santri }}{\text { Total jumlah seluruh santri }} \times 100 \%$
2) Kesehatan (M2) $=\frac{\text { Jumlah santri yang sakit (ringan,sedang,berat) }}{\text { Total jumlah seluruh santri }} \times 100 \%$
3) Kecukupan pangan (M3) $=\frac{\text { Jumlah stok pangan yang tidak terdistribusi }}{\text { Total jumlah seluruh santri }} \times 100 \%$

c. Mengukur kinerja bulanan

Rasio-rasio yang dipilih melalui 52 standar minimum pondok pesantren yang diacu untuk mewakili kinerja bulanan:

1) Efisiensi keuangan (B1) $=\frac{\text { Jumlah realisasi belanja operasional }}{\text { Realisasi pendapatan usaha }} \times 100 \%$

2) Inovasi layanan (B2) $=\frac{\text { Jumlah pembaruan layanan }}{\text { Total jumlah seluruh layanan }} \times 100 \%$ 
Jurnal Riset Sistem Informasi Dan Teknik Informatika (JURASIK)

Volume 5 Nomor 1 Februari, pp 127-137

ISSN: 2527-5771/EISSN: 2549-7839

http://tunasbangsa.ac.id/ejurnal/index.php/jurasik

3) Keberhasilan program (B3) $=\frac{\text { Jumlah program terealisasi }}{\text { Total seluruh rancangan program }} \times 100 \%$

d. Mengukur kinerja tahunan

Rasio-rasio yang dipilih melalui 52 standar minimum pondok pesantren yang diacu untuk mewakili kinerja tahunan:

1) Pencapaian total (T1) = $\frac{\text { Jumlah angka ketuntasan visi misi }}{\text { Angka harapan ketuntasan visi misi }} \times 100 \%$

2) Kelayakan (T2) = Jumlah layanan dan fasilitas yang $\times 100 \%$

3) Kepuasan(T3) $=\frac{\text { Angka kenyataan survei kepuasan }}{\text { Angka harapan survei kepuasan }} \times 100 \%$

\subsection{Membuat matriks perbandingan berpasangan}

Setiap kriteria dan alternatif guna mendapatkan nilai kepentingan secara kuantitatif menggunakan skala yang ditentukan.

a. Kinerja harian

Tabel 3. Kinerja harian pondok pesantren

\begin{tabular}{|l|l|l|l|}
\hline & $\mathrm{H} 1$ & $\mathrm{H} 2$ & $\mathrm{H} 3$ \\
\hline $\mathrm{H} 1$ & 1 & $1 / 3$ & $1 / 2$ \\
\hline $\mathrm{H} 2$ & 3 & 1 & $1 / 2$ \\
\hline $\mathrm{H} 3$ & 2 & 2 & 1 \\
\hline
\end{tabular}

b. Kinerja mingguan

Tabel 4. Kinerja mingguan pondok pesantren

\begin{tabular}{|l|l|l|l|}
\hline & M1 & M2 & M3 \\
\hline M1 & 1 & $1 / 3$ & $1 / 2$ \\
\hline M2 & 3 & 1 & $1 / 3$ \\
\hline M3 & 2 & 3 & 1 \\
\hline
\end{tabular}

c. Kinerja bulanan

Tabel 5. Kinerja bulanan pondok pesantren

\begin{tabular}{|l|l|l|l|}
\hline & B1 & B2 & B3 \\
\hline B1 & 1 & $1 / 5$ & $1 / 4$ \\
\hline B2 & 5 & 1 & $1 / 5$ \\
\hline B3 & 4 & 5 & 1 \\
\hline
\end{tabular}

d. Kinerja tahunan

Tabel 6. Kinerja tahunan pondok pesantren

\begin{tabular}{|l|l|l|l|}
\hline & T1 & T2 & T3 \\
\hline T1 & 1 & $1 / 3$ & $1 / 2$ \\
\hline T2 & 3 & 1 & $1 / 5$ \\
\hline T3 & 2 & 5 & 1 \\
\hline
\end{tabular}

Pengukuran Kinerja Pondok Pesantren Menggunakan AHP (Nur Kartika Oktafiani)|132 


\subsection{Melakukan perhitungan dengan AHP Calculator}

a. Hasil untuk kinerja harian

Tabel 7. Hasil kinerja harian pondok pesantren

\begin{tabular}{|l|l|l|l|l|l|}
\hline & Priority & Priority & Rank & $(+)$ & $(-)$ \\
\hline 1. & Keaktifan & $54,7 \%$ & 1 & $19,7 \%$ & $19,7 \%$ \\
\hline 2. & Keamanan & $26,3 \%$ & 2 & $9,5 \%$ & $9,5 \%$ \\
\hline 3. & Kebersihan & $19,0 \%$ & 3 & $6,8 \%$ & $6,8 \%$ \\
\hline
\end{tabular}

Jumlah Perbandingan $=3$

$\mathrm{CR}=14,1 \%$

Tabel 8. Matriks keputusan kinerja harian pondok pesantren

\begin{tabular}{|l|l|l|l|}
\hline & 1 & 2 & 3 \\
\hline 1 & 1 & 3,00 & 2,00 \\
\hline 2 & 0,33 & 1 & 2,00 \\
\hline 3 & 0,50 & 0,50 & 1 \\
\hline
\end{tabular}

Nilai eigen utama $=3,136$

Solusi vector eigen $=5$ perulangan

Delta $=1,5 \mathrm{E}-8$

Berikut adalah grafik hasil kinerja harian pondok pesantren seperti yang ditunjukkan pada gambar berikut:

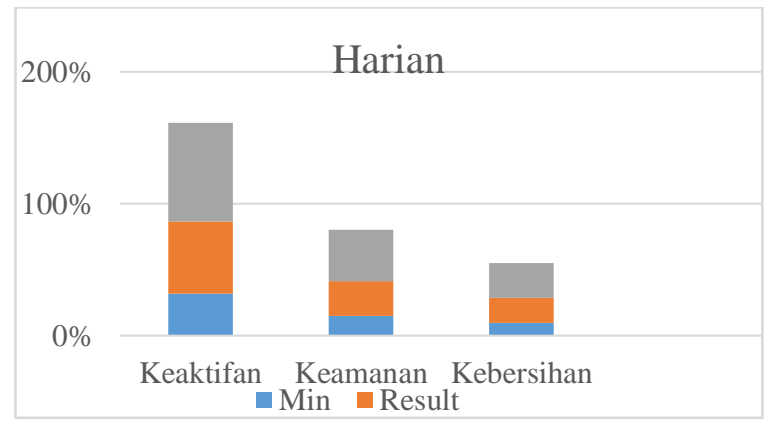

Gambar 2. Grafik hasil kinerja harian pondok pesantren

b. Hasil untuk kinerja mingguan

Tabel 9. Hasil kinerja mingguan pondok pesantren.

\begin{tabular}{|l|l|l|l|l|l|}
\hline & Priority & Priority & Rank & $(+)$ & $(-)$ \\
\hline 1. & Ketertiban & $54,0 \%$ & 1 & $26,2 \%$ & $26,2 \%$ \\
\hline 2. & Kesehatan & $29,7 \%$ & 2 & $14,4 \%$ & $14,4 \%$ \\
\hline 3. & Kecukupan Pangan & $16,3 \%$ & 3 & $7,9 \%$ & $7,9 \%$ \\
\hline
\end{tabular}

Jumlah Perbandingan $=3$

$\mathrm{CR}=26,8 \%$ 
Jurnal Riset Sistem Informasi Dan Teknik Informatika (JURASIK)

Volume 5 Nomor 1 Februari, pp 127-137

ISSN: 2527-5771/EISSN: 2549-7839

http://tunasbangsa.ac.id/ejurnal/index.php/jurasik

Tabel 10. Matriks keputusan kinerja mingguan pondok pesantren.

\begin{tabular}{|l|l|l|l|}
\hline & 1 & 2 & 3 \\
\hline 1 & 1 & 3,00 & 2,00 \\
\hline 2 & 0,33 & 1 & 3,00 \\
\hline 3 & 0,50 & 0,33 & 1 \\
\hline
\end{tabular}

Nilai eigen utama $=3,257$

Solusi vector eigen $=6$ perulangan

Delta $=1.0 \mathrm{E}-8$

Berikut adalah grafik hasil kinerja harian pondok pesantren seperti yang ditunjukkan pada gambar berikut:

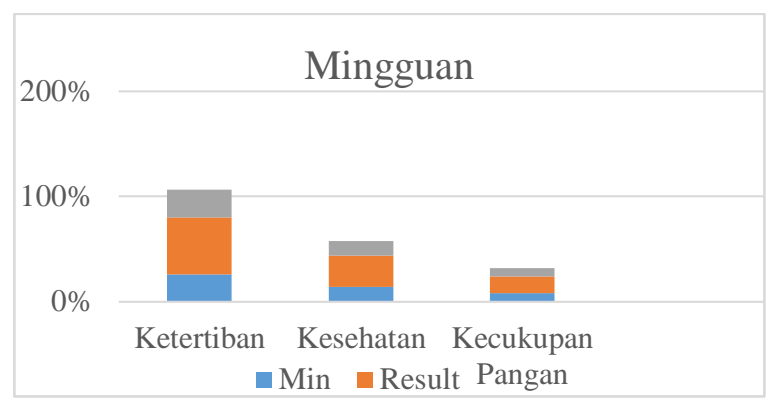

Gambar 3. Grafik hasil kinerja mingguan

c. Hasil untuk kinerja bulanan

Tabel 11. Hasil kinerja Bulanan pondok pesantren

\begin{tabular}{|l|l|l|l|l|l|}
\hline & Priority & Priority & Rank & $(+)$ & $(-)$ \\
\hline 1. & Efisiensi Keuangan & $66,5 \%$ & 1 & $38,8 \%$ & $38,8 \%$ \\
\hline 2. & Inovasi Layanan & $24,5 \%$ & 2 & $14,3 \%$ & $14,3 \%$ \\
\hline 3. & Keberhasilan Program & $9,0 \%$ & 3 & $5,3 \%$ & $5,3 \%$ \\
\hline
\end{tabular}

Jumlah Perbandingan $=3$

$\mathrm{CR}=40,2 \%$

Tabel 12. Matriks keputusan kinerja Bulanan pondok pesantren

\begin{tabular}{|l|l|l|l|}
\hline & 1 & 2 & 3 \\
\hline 1 & 1 & 5,00 & 4,00 \\
\hline 2 & 0,20 & 1 & 5,00 \\
\hline 3 & 0,25 & 0,20 & 1 \\
\hline
\end{tabular}

Nilai eigen utama $=3,385$

Solusi vector eigen $=7$ perulangan

Delta $=2.8 \mathrm{E}-8$ 
Jurnal Riset Sistem Informasi Dan Teknik Informatika (JURASIK)

Volume 5 Nomor 1 Februari, pp 127-137

ISSN: 2527-5771/EISSN: 2549-7839

http://tunasbangsa.ac.id/ejurnal/index.php/jurasik

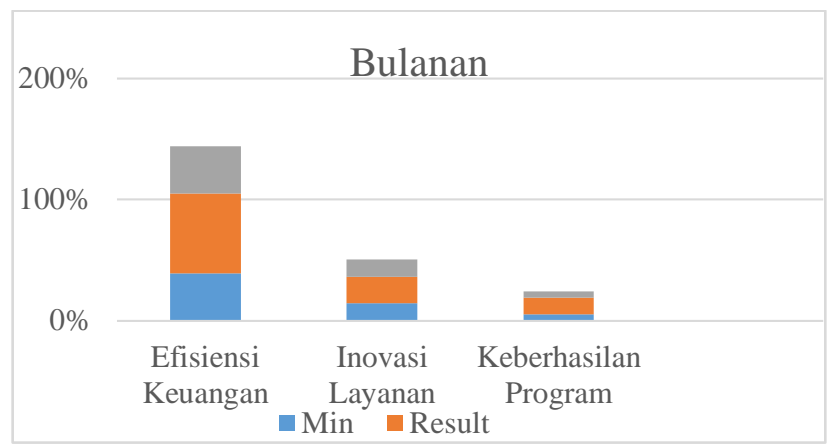

Gambar 4. Grafik hasil kinerja bulanan pondok pesantren

d. Hasil untuk kinerja tahunan

Tabel 13. Hasil kinerja tahunan pondok pesantren.

\begin{tabular}{|l|l|l|l|l|l|}
\hline & Priority & Priority & Rank & $(+)$ & $(-)$ \\
\hline 1. & Pencapaian & $52,4 \%$ & 1 & $33,4 \%$ & $33,4 \%$ \\
\hline 2. & Kelayakan & $34,2 \%$ & 2 & $21,8 \%$ & $21,8 \%$ \\
\hline 3. & Kepuasan & $13,4 \%$ & 3 & $8,5 \%$ & $8,5 \%$ \\
\hline
\end{tabular}

Jumlah Perbandingan $=3$

$\mathrm{CR}=48,9 \%$

Tabel 14 Matriks keputusan tahunan pondok pesantren

\begin{tabular}{|l|l|l|l|}
\hline & 1 & 2 & 3 \\
\hline 1 & 1 & 3,00 & 2,00 \\
\hline 2 & 0,33 & 1 & 5,00 \\
\hline 3 & 0,50 & 0,20 & 1 \\
\hline
\end{tabular}

Nilai eigen utama $=3,468$

Solusi vector eigen $=9$ perulangan

Delta $=1.9 \mathrm{E}-9$

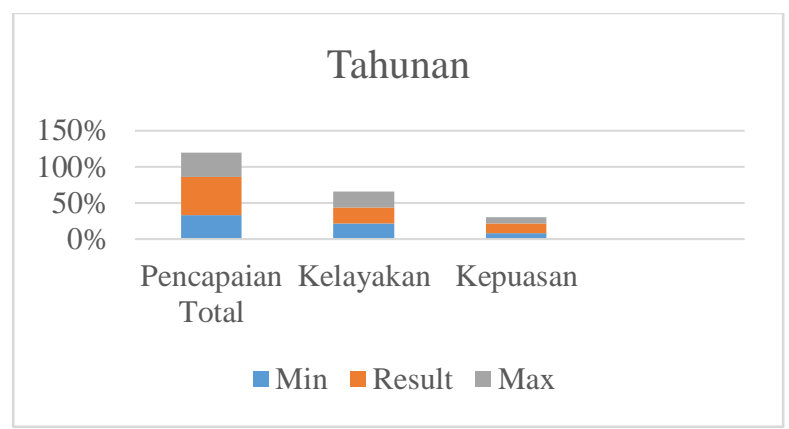

Gambar 5. Grafik hasil kinerja tahunan pondok pesantren 


\subsection{Studi Kasus: Pengukuran Kinerja Pondok Pesantren X}

Pondok pesantren $\mathrm{X}$ merupakan sebuah pondok pesantren yang terletak di kota $Y$ dengan jumlah santri 200 orang. Pondok pesantren Y memiliki 50 ruangan dengan beberapa layanan dan fasilitas yang tersedia. Berikut perhitungan untuk kinerja pondok pesantren $\mathrm{X}$ berdasarkan uraian diatas:

\section{a. Kinerja Harian}

1) Keaktifan (H1) $=\frac{170}{200} \times 100 \%=85 \%$

2) Keamanan $(\mathrm{H} 2)=\frac{182}{200} \times 100 \%=91 \%$

3) Kebersihan (H3) $=\frac{46}{50} \times 100 \%=92 \%$

Maka, dapat dihitung nilai kinerja hariannya yaitu:

Kinerja Harian $\quad=\left(\mathrm{H} 1 \cdot \mathrm{PH}_{1}\right)+\left(\mathrm{H} 2 \cdot \mathrm{PH}_{2}\right)+\left(\mathrm{H}_{3} \cdot \mathrm{PH}_{3}\right)$

$$
\begin{aligned}
& =(85 \% \times 54,7 \%)+(91 \% \times 26,3 \%)+(92 \% \times 19 \%) \\
& =0,87
\end{aligned}
$$

Jadi nilai kinerja harian pondok pesantren $\mathrm{X}$ adalah $87 \%$

\section{b. Kinerja Mingguan}

1) Ketertiban (M1) $=\frac{20}{200} \times 100 \%=10 \%$

2) Kesehatan (M2) $=\frac{35}{200} \times 100 \%=17,5 \%$

3) Kecukupan (M3) $=\frac{29}{200} \times 100 \%=14,5 \%$

Maka, dapat dihitung nilai kinerja mingguannya yaitu:

Kinerja Harian $\quad=\left(\mathrm{M}_{1} \cdot \mathrm{PM}_{1}\right)+\left(\mathrm{M}_{2} \cdot \mathrm{PM}_{2}\right)+\left(\mathrm{M}_{3} \cdot \mathrm{PM}_{3}\right)$

$$
=(10 \% \times 54 \%)+(17,5 \% \times 29,3 \%)+(14,5 \% \times 16,3 \%)
$$$$
=0,26
$$

Jadi nilai kinerja mingguan pondok pesantren X adalah 26\%

\section{c. Kinerja Bulanan}

1) Efisiensi(B1) $=\frac{189}{200} \times 100 \%=94,5 \%$

2) Inovasi (B2) $=\frac{20}{25} \times 100 \%=80 \%$

3) Keberhasilan (B3) $=\frac{29}{30} \times 100 \%=96,7 \%$

Maka, dapat dihitung nilai kinerja bulanannya yaitu:

Kinerja Bulanan $=\left(\mathrm{B} 1 \cdot \mathrm{PB}_{1}\right)+\left(\mathrm{B} 2 \cdot \mathrm{PB}_{2}\right)+\left(\mathrm{B}_{3} \cdot \mathrm{PB}_{3}\right)$

$$
\begin{aligned}
& =(94,5 \% \times 65,4 \%)+(80 \% \times 24,5 \%)+(96,7 \% \times 9 \%) \\
& =0,90
\end{aligned}
$$

Jadi nilai kinerja bulanan pondok pesantren X adalah $90 \%$

\section{d. Kinerja Tahunan}

1) Pencapain (T1) $=\frac{59}{60} \times 100 \%=98,3 \%$ 
Jurnal Riset Sistem Informasi Dan Teknik Informatika (JURASIK)

Volume 5 Nomor 1 Februari, pp 127-137

ISSN: 2527-5771/EISSN: 2549-7839

http://tunasbangsa.ac.id/ejurnal/index.php/jurasik

2) Kelayakan (T2) $=\frac{45}{50} \times 100 \%=90 \%$

3) Kepuasan (T3) $=\frac{25}{30} \times 100 \%=83 \%$

Maka, dapat dihitung nilai kinerja tahunannya yaitu:

Kinerja Tahunan $=\left(\mathrm{T}_{1} \cdot \mathrm{PT} \mathrm{T}_{1}\right)+\left(\mathrm{T}_{2} \cdot \mathrm{PT}_{2}\right)+\left(\mathrm{T}_{3} \cdot \mathrm{PT}_{3}\right)$

$=(93,3 \% \times 52,4 \%)+(90 \% \times 34,2 \%)+(83 \% \times 13,4 \%)$

$=0,91$

Jadi nilai kinerja tahunan pondok pesantren X adalah 91\%

\section{SIMPULAN}

Berdasarkan tujuan penelitian serta hasil pembahasan penelitian yang dijelaskan pada bab sebelumnya didapatkan kesimpulan bahwa untuk mengetahui keberhasilan kinerja Pondok Pesantren diperlukan pengukuran untuk kinerjanya. Salah satu metode yang digunakan untuk melakukan pengukuran kinerja adalah metode AHP. Pada penelitian ini pengukuran kinerja Pondok Pesantren menggunakan metode AHP memerlukan beberapa kriteria. Dari kriteria itu di kelompokkan menjadi kinerja harian, kinerja mingguan, kinerja bulanan dan kinerja tahunan. Dimana setelah dihitung keaktifan, ketertiban, efisiensi keuangan dan pencapaian merupakan hal yang paling utama dalam keberhasilan pondok pesantren.

\section{DAFTAR PUSTAKA}

[1] Yaqin H, 2012. ISLAMIC BOARDING SCHOOL CURRICULUM IN INDONESIA: A Case Study In Islamic Boarding Shool In South Kalimantan. Jurnal Al-Hikmah Vol. XIII Nomor $1 / 2012$.

[2] Devani Vera, 2016. Pengukuran Kinerja Perpustakaan Dengan Pendekatan Balanced Scorecard. JITI, Vol.15 (1), Jun 2016, 27 - 35.

[3] Ilhami, Rizka Soumil, Rimantho, Dino, 2017. Penilaian Kinerja Karyawan dengan Metode AHP dan Rating Scale, Jurnal Optimasi Sistem Industri - Vol. 16 No. 2 (2017) 150-157.

[4] Abushaiba I, A \& Zainuddin, Y, 2012. Performance Measurement System Design, Competitive Capability, and Performance Consequences - A Conceptual Like. International Journal of Business and Social Science.

[5] Zaidah, yanus, 2010. Pengukuran Kinerja Fakultas Teknik Universitas Trunojoyo Menggunakan Academic Scorecard (ASC) dengan Metode Analytical Hierarchy Process (AHP). Rekayasa, Volume 3, Nomor 2.

[6] Putri, Chauliah Fatma, 2012. Pemilihan Supplier Bahan Baku Pengemas Dengan Metode Ahp (Analytical Hierarchy Process). Widya Teknika Vol.20 No.1; 